\title{
A novel cytochrome P450 1D1 gene in Nile tilapia fish (Oreochromis niloticus): partial cDNA cloning and expression following benzo-a-pyrene exposure
}

\author{
Abeer A. I. Hassanin • Yoshio Kaminishi \\ Received: 14 February 2019/Accepted: 14 August 2019/Published online: 23 August 2019 \\ (C) The Author(s) 2019
}

\begin{abstract}
To understand the detoxification and bioactivation mechanisms for organic contaminants, it is essential to identify the cytochrome P450 (CYP) complement. Therefore, this study aimed to clone a partial cDNA sequence of the novel CYP1D1 gene from the fish Oreochromis niloticus and examine whether intraperitoneal injection of benzo-a-pyrene (BaP), a potent AHR agonist, is capable of inducing CYP1D1 mRNA expression in different tilapia fish tissues. The cloned nucleotide sequence consisted of $713 \mathrm{bp}$ representing a portion of the tilapia CYP1D1 cDNA ORF, encoding 237 amino acids. Amino acid sequence comparison of $O$. niloticus CYP1D1 with the sequences of CYP1D1 from other species showed that this gene shared the highest identity of $81 \%$ with Fundulus heteroclitus CYP1D1. Furthermore, analysis of the percent identities shared by the deduced amino acid sequence of $O$. niloticus CYP1D1 with the sequences of CYP1 from other species revealed that the highest identities were shared with fish CYP1As. Real-time PCR results revealed that the highest expression level of CYP1D1 mRNA was found in muscles, followed by gills, liver, and intestine, while there was no detectable expression recorded in bile acid. These results indicate that tilapia CYP1D1 plays an important role in the metabolism of xenobiotics, expanding our knowledge regarding the diversity of CYP1 genes in this important model fish species.
\end{abstract}

Keywords Tilapia $\cdot$ CYP1D1 $\cdot \mathrm{BaP} \cdot$ Cloning $\cdot$ Real-time PCR

\section{Introduction}

Aquatic ecosystems harbor large amounts of persistent pollutants, such as dioxins, planar polychlorinated biphenyls (PCBs), and polycyclic aromatic hydrocarbons (PAHs). PAHs are a very large family of more than 100 compounds that contain at least 2 aromatic rings. The main source of PAH toxicity in wild-caught fish is oil spill exposure (Cousin and Cachot 2014).

Biomarkers in fish can be used as early warning signs of the deterioration of aquatic environments, which may allow environmental management to mitigate potential adverse impacts at higher levels of biological organization. To date, little is known about the aryl hydrocarbon receptor (AHR)-regulated genes responsible

\footnotetext{
A. A. I. Hassanin ( $\square)$

Department of Animal Wealth Development, Faculty of Veterinary Medicine, Suez Canal University, Ismailia, Egypt e-mail: drabeer2000@gmail.com

A. A. I. Hassanin - Y. Kaminishi

Laboratory of Marine Biotechnology, Faculty of Fisheries, Kagoshima University, Kagoshima, Japan
} 
for the impacts of PAHs. However, genes in the cytochrome P450 1 (CYP1) family are considered to be among the most sensitive indicators involved in PAH bioactivation (Nebert and Russell 2002).

The induction of CYP1A by PAHs in fish has been used as a biomarker of exposure since the mid-1970s (Payne and Penrose 1975). Moreover, recently, CYP1B genes were also shown to be activated by PAHs in the same manner as the CYP1A family, and the associated protein products metabolize PAHs (Savas et al. 1994; Zhang et al. 1998; Hassanin et al. 2013).

CYP1C genes have been cloned from the genomes of several species, such as bird, frog, and fish genomes (Goldstone et al. 2007). In fish, PCB126, 2,3,7,8-tetrachlorodibenzo-p-dioxin (TCDD), and PAHs are capable of inducing CYP1Cs in both embryonic and adult stages (Jönsson et al. 2007; Zanette et al. 2009; Jönsson et al. 2010; Hassanin et al. 2012).

Human CYP1D1P (formerly known as CYP1A8P) has five nonsense mutations in the putative coding region of exons 2 and 7 and is, therefore, not expected to encode a functional protein (Uno et al. 2011). CYP1D1 was cloned from zebrafish and killifish (Zanette et al. 2009) and shared the highest amino acid sequence identity with CYP1A (55-56\%). However, the discovery of functional CYP1D1 in fish introduced the possibility that the CYP1D1 in fish genomes, lacking nonsense mutations, could be expressed as a functional enzyme in other species. However, the low response of this gene towards different substrates and inducers raises doubts regarding the role of such genes in xenobiotic metabolism (Saad et al. 2016).

Benzo-a-pyrene $(\mathrm{BaP})$ is a pervasive, cancer-causing, mutagenic PAH (Office of the Federal Registration (OFR) 1982; Tsuji and Walle 2007) that causes dramatic changes in fish biomarkers after short-term exposure (Peters et al. 1997; Gravato and Santos 2003).

Nile tilapia (Oreochromis niloticus) is considered an ideal model in toxicological research for many reasons, including ease of handling and maintenance in the laboratory. Furthermore, this species speedily responds to environmental alterations (Almeida et al. 2002; Figueiredo-Fernandes et al. 2006). The complete sequence of the tilapia CYP1D1 gene is available in the Ensembl database (http://asia.ensembl.org/Oreo chromis_niloticus/Gene/Sequence?db=core;g=ENSONIG00000010740;r=GL831172.1:920994-929301;t= ENSONIT00000013514). In contrast to other CYP1 isoforms, the promoter region of the CYP1D1 gene contains few xenobiotic-responsive element (XRE)-like sequences (Kawai et al. 2012). Therefore, analysis of tilapia CYP1D1 can provide new insight into the relationship between this gene and AHRs.

Thus, this study aimed to clone a partial cDNA sequence of Nile tilapia CYP1D1 and characterize this sequence by sequence analysis, phylogenetic analysis, and expression pattern analysis in different tissues of fish treated with $\mathrm{BaP}$.

\section{Materials and methods}

Fish handling and treatment

Forty male Nile tilapia (O. niloticus) with a mean weight of $500 \mathrm{~g}$ were purchased from a local Japanese fish farm and acclimated for 2 weeks, during which the fish were fed a commercial standard dry diet twice a day. The fish were then divided into two groups, namely the control and treated groups, with 20 fish in each group. Fish in the treated group were first anesthetized by immersing in crushed ice (Summerfelt and Smith 1990) followed by intracoelomic injection (in an area that is in front of but slightly off-center from the anus or vent) with a single dose of $\mathrm{BaP}(100 \mathrm{mg} / \mathrm{kg}$ body weight), which was suspended in corn oil before application and used fresh. Fish in the control group were injected with the same volume of corn oil as a vehicle after being anesthetized as mentioned above. Twenty-four hours later, the fish in both groups were killed; liver, intestine, gill, bile acid, and muscle tissue samples were collected, frozen in liquid nitrogen and stored at $-80{ }^{\circ} \mathrm{C}$ until analysis. 
Cloning of a partial cDNA sequence of tilapia CYP1D1

\section{Total RNA extraction and reverse transcriptase-assisted PCR}

Total RNA was extracted from different tissues of tilapia using Isogen reagent (Nippon Gene Co., Ltd.) according to the manufacturer's protocol. The purity and concentration of the extracted RNA samples were determined spectrophotometrically as described by Sambrook and Russel (2001). The A260/A280 ratio ranged from 1.7 to 1.9 , and mRNA reverse transcription was performed using Superscript II reverse transcriptase (Gibco BRL, USA) to generate $5^{\prime}$-RACE-ready and $3^{\prime}$-RACE-ready first-strand cDNA using the SMART ${ }^{\mathrm{TM}}$ RACE cDNA Amplification Kit (Clontech, USA) according to the manufacturer's protocol.

\section{Oligonucleotide primers and PCR amplification of the tilapia CYP1D1 cDNA fragment}

Two degenerate primers (Genenet.co.jp) were designed using highly conserved regions of both the Fundulus heteroclitus CYP1D1 sequence (accession number NM_001309918) and Danio rerio CYP1D1 sequence (accession number NM_001007310), which are retrievable from GenBank. The nucleotide sequences for the primers used were as follows: sense primer (5'-GGS AAY YTK YTC CAG VTK GR- $3^{\prime}$; where $\mathrm{S}$ is G or C; Y is $\mathrm{C}$ or $\mathrm{T} ; \mathrm{K}$ is $\mathrm{G}$ or $\mathrm{T}$; $\mathrm{V}$ is $\mathrm{A}, \mathrm{C}$ or $\mathrm{G}$; and $\mathrm{R}$ is $\mathrm{A}$ or $\mathrm{G}$ ) and antisense primer (5'-AGR GCA TCW GTR ATR TCY CK- $3^{\prime}$; where $\mathrm{R}$ is A or $\mathrm{G}$; $\mathrm{W}$ is $\mathrm{A}$ or $\mathrm{T}$; $\mathrm{Y}$ is $\mathrm{C}$ or $\mathrm{T}$; and $\mathrm{K}$ is $\mathrm{G}$ or $\mathrm{T}$ ). The PCR was performed as follows: 35 cycles of denaturation at $94{ }^{\circ} \mathrm{C}$ for $30 \mathrm{~s}$, annealing at $55{ }^{\circ} \mathrm{C}$ for $30 \mathrm{~s}$ and extension at $72{ }^{\circ} \mathrm{C}$ for $3 \mathrm{~min}$. Then $1 \%$ agarose gels were used to examine the PCR products. The DNA band of the expected size was excised, purified using the GFX PCR DNA and Gel Band Purification Kit (GE Health Care, UK), and then cloned into the PT7Blue T-vector (Novagen, USA). The purified plasmids were directly sequenced by dye terminator cycle sequencing using the ABI PRISM Dye Terminator Cycle Sequencing Kit (PE Biosystems, USA) and an Applied Biosystems 3130xl DNA sequencer.

Phylogenetic analysis

To construct the CYP1D1 gene family phylogenetic tree for various fish species, the CYP1D1 mRNA sequences with the following GenBank accession numbers were obtained from the database and used: NM_001007310 (zebrafish CYP1D1), JX454650 (Indian medaka CYP1D1), FJ786961 (killifish CYP1D1), NM_001246671 (rhesus monkey CYP1D1), and NM_001126813 (tropical clawed frog CYP1D1).

Furthermore, to construct the phylogenetic tree of CYP1 gene families from different species, the CYP1 sequences with the following GenBank accession numbers were obtained from the database and used: AB015638 (Japanese eel CYP1A1), AB020414 (Japanese eel CYP1A9), AF210727 (zebrafish CYP1A1), X73631 (plaice CYP1A1), U14162 (scup CYP1A1), FJ389918 (tilapia CYP1A1), K03191 (human CYP1A1), BC125440 (mouse CYP1A1), NM_000761 (human CYP1A2), NM_009993 (mouse CYP1A2), HQ829968 (tilapia CYP1B1), XM_003978309 (fugu CYP1B1), AB048942 (common carp CYP1B1), HQ829969 (tilapia CYP1C1), AY444748 (Japanese eel CYP1C1), and L04751 (human CYP4A). Sequence alignment was performed by the Clustal W method using the Lasergene MegAlign program (Ver 5.52,2003, DNASTAR Inc).

\section{Expression of CYP1D1 mRNA in different tissues of tilapia fish}

Real-time quantitative PCR was performed using Fast Start Essential DNA Green Master (Roche, 06402712001) and a LightCycler Nano system (Roche Applied Science). A total of 30 tissue samples were used in this experiment. Three samples from each of liver, gills, intestine, bile acid, and muscle tissues were taken from fish in the control group, and a similar number of samples was obtained from the treated group. RNA reverse transcription was performed using the PrimeScript ${ }^{\mathrm{TM}}$ 1st strand cDNA Synthesis Kit (Takara, Japan) according to the manufacturer's protocol. Primers for $O$. niloticus CYP1D1 cDNA and internal control ( $\beta$-actin) cDNA (accession number EU887951) are listed in Table 1. Each PCR consisted of $2 \times$ Master Mix $(10 \mu \mathrm{l})$, primers $\left(10 \mu \mathrm{M}\right.$ each), cDNA template $(2 \mu \mathrm{l})$ and $\mathrm{ddH}_{2} \mathrm{O}$ to a final volume of $20 \mu \mathrm{l}$. Reactions were then performed as follows: initial denaturation at $95^{\circ} \mathrm{C}$ for $10 \mathrm{~min} ; 35$ cycles of $95{ }^{\circ} \mathrm{C}$ for $10 \mathrm{~s}, 60{ }^{\circ} \mathrm{C}$ for 
Table 1 Real-time PCR primers for the Oreochromis niloticus CYP1D1 and $\beta$-actin genes

\begin{tabular}{lllll}
\hline Gene & Primer description & Sequence $\left(5^{\prime}-3^{\prime}\right)$ & Location & Product size \\
\hline CYP1D1 & $\mathrm{F}$ & 5'-AGGGATGGTGCAGGTGATTC-3' $^{\prime}$ & $357-376$ & $113 \mathrm{bp}$ \\
& $\mathrm{f}$ & & & \\
& $\mathrm{R}$ & $5^{\prime}$-CCAAAACAGAGCGCACAGAC-3' & $451-470$ & $143 \mathrm{bp}$ \\
$\beta$-Actin & $\mathrm{F}$ & 5'-GGGTCAGAAAGACAGCTACGTT-3' $^{\prime}$ & $42-63$ & \\
& $\mathrm{R}$ & 5'-CTCAGCTCGTTGTAGAAGGTGT-3' $^{\prime}$ &
\end{tabular}

$10 \mathrm{~s}$, and $72{ }^{\circ} \mathrm{C}$ for $15 \mathrm{~s}$; one cycle of $95{ }^{\circ} \mathrm{C}$ for $30 \mathrm{~s}$; and one cycle of $60{ }^{\circ} \mathrm{C}$ for $20 \mathrm{~s}$ and $95{ }^{\circ} \mathrm{C}$ for $20 \mathrm{~s}$. Each PCR run included an RT-negative control for each gene and a no-template control. All samples for each gene were run in triplicate on the same plate. Quantitative analysis of gene expression was performed using the geometric mean for the internal control genes according to a previously described equation (Hellemans et al. 2007).

\section{Results}

Partial nucleotide sequence of tilapia cytochrome P450 1D1 cDNA and its deduced amino acid residues

Tilapia CYP1D1 cDNA was identified using the two degenerate primers designed using the highly conserved regions of both the $F$. heteroclitus CYP1D1 and D. rerio CYP1D1 sequences as mentioned earlier. The obtained PCR fragment was then cloned and sequenced. The nucleotide sequence consisted of $713 \mathrm{bp}$,

GGG AAC TTT CTC CAg GTT GGg GAg CAg ATT CAT CTC TCT TTA ACT GGG TTG AGg CTT CAg 60

$\begin{array}{lllllllllllllllllllllllll}\text { G } & \text { N } & \text { F } & \text { L } & \text { Q } & \text { V } & \text { G } & \text { E } & \text { Q } & \text { I } & \text { H } & \text { L } & \text { S } & \text { L } & \text { T } & \text { G } & \text { L } & \text { R } & \text { L } & \text { Q } & & 20\end{array}$

TAt GGA GAC ATC TTC AAg CTC CGC CTT GGC TCT TTG ACT GTT GTC GTT CTg Agt GgG tAC 120

$\begin{array}{lllllllllllllllllllllllll}\mathrm{Y} & \mathrm{G} & \mathrm{D} & \mathrm{I} & \mathrm{F} & \mathrm{K} & \mathrm{L} & \mathrm{R} & \mathrm{L} & \mathrm{G} & \mathrm{S} & \mathrm{L} & \mathrm{T} & \mathrm{V} & \mathrm{V} & \mathrm{V} & \mathrm{L} & \mathrm{S} & \mathrm{G} & \mathrm{Y} & & 40\end{array}$

AAC ACC ATC AGG CAG GCT CTG GTT CGA CAC GGG GAA GCT TTT GCG GGG CGA CCT AAC CTT 180

$\begin{array}{lllllllllllllllllllllllll}\mathrm{N} & \mathrm{T} & \mathrm{I} & \mathrm{R} & \mathrm{Q} & \mathrm{A} & \mathrm{L} & \mathrm{V} & \mathrm{R} & \mathrm{H} & \mathrm{G} & \mathrm{E} & \mathrm{A} & \mathrm{F} & \mathrm{A} & \mathrm{G} & \mathrm{R} & \mathrm{P} & \mathrm{N} & \mathrm{L} & & 60\end{array}$

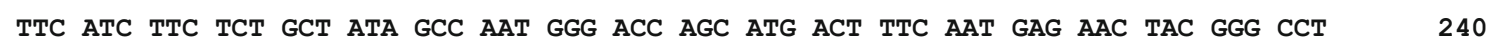

$\begin{array}{lllllllllllllllllllllll}\mathrm{F} & \mathrm{I} & \mathrm{F} & \mathrm{S} & \mathrm{A} & \mathrm{I} & \mathrm{A} & \mathrm{N} & \mathrm{G} & \mathrm{T} & \mathrm{S} & \mathrm{M} & \mathrm{T} & \mathrm{F} & \mathrm{N} & \mathrm{E} & \mathrm{N} & \mathrm{Y} & \mathrm{G} & \mathrm{P} & & 80\end{array}$

GTG TGG CTG CTC CAT AAg AAG CTG TGT AAG AAT GCC CTC AGG TCT TTC TCC CAG GCT GAg 300

$\begin{array}{lllllllllllllllllllllll}\mathrm{V} & \mathrm{W} & \mathrm{L} & \mathrm{L} & \mathrm{H} & \mathrm{K} & \mathrm{K} & \mathrm{L} & \mathrm{C} & \mathrm{K} & \mathrm{N} & \mathrm{A} & \mathrm{L} & \mathrm{R} & \mathrm{S} & \mathrm{F} & \mathrm{S} & \mathrm{Q} & \mathrm{A} & \mathrm{E} & & 100\end{array}$

CCA AGG GGT TTT GGT GCC ACC TGC CTC TTA GAG GAG CAC ATA TGT GCA GAG GCT GCA GGG 360

$\begin{array}{llllllllllllllllllllllllll}\mathrm{P} & \mathrm{R} & \mathrm{G} & \mathrm{F} & \mathrm{G} & \mathrm{A} & \mathrm{T} & \mathrm{C} & \mathrm{L} & \mathrm{L} & \mathrm{E} & \mathrm{E} & \mathrm{H} & \mathrm{I} & \mathrm{C} & \mathrm{A} & \mathrm{E} & \mathrm{A} & \mathrm{A} & \mathrm{G} & & 120\end{array}$

ATG GTG CAG GTG ATT CGA GAA AAA GCT GCT AAA GAG GAC ATG GAG GGT ATA GAC CCA GCA 420

$\begin{array}{lllllllllllllllllllllll}\mathrm{M} & \mathrm{V} & \mathrm{Q} & \mathrm{V} & \mathrm{I} & \mathrm{R} & \mathrm{E} & \mathrm{K} & \mathrm{A} & \mathrm{A} & \mathrm{K} & \mathrm{E} & \mathrm{D} & \mathrm{M} & \mathrm{E} & \mathrm{G} & \mathrm{I} & \mathrm{D} & \mathrm{P} & \mathrm{A} & & 140\end{array}$

ACG ACC TTG GTA ACC TCA GTG GCA AAT GTC GTC TGT GCG CTC TGT TTT GGG AAA CGG TAT 480

$\begin{array}{lllllllllllllllllllllll}\mathrm{T} & \mathrm{T} & \mathrm{L} & \mathrm{V} & \mathrm{T} & \mathrm{S} & \mathrm{V} & \mathrm{A} & \mathrm{N} & \mathrm{V} & \mathrm{V} & \mathrm{C} & \mathrm{A} & \mathrm{L} & \mathrm{C} & \mathrm{F} & \mathrm{G} & \mathrm{K} & \mathrm{R} & \mathrm{Y} & & 160\end{array}$

GAC TAC AGT GAT AAG GAG TTT CTC ACT ATT GTT GAT GTC AAC AAC GAG GTC CTG AAg CTC 540

$\begin{array}{lllllllllllllllllllllllll}\mathrm{D} & \mathrm{Y} & \mathrm{S} & \mathrm{D} & \mathrm{K} & \mathrm{E} & \mathrm{F} & \mathrm{L} & \mathrm{T} & \mathrm{I} & \mathrm{V} & \mathrm{D} & \mathrm{V} & \mathrm{N} & \mathrm{N} & \mathrm{E} & \mathrm{V} & \mathrm{L} & \mathrm{K} & \mathrm{L} & & 180\end{array}$

TTT GCA GCG GGG AAC CTG GCT GAT TTC TTC CCC GTG TTT CGC TAC TTT CCG AGT CCA TCT 600

$\begin{array}{lllllllllllllllllllllllll}\mathrm{F} & \mathrm{A} & \mathrm{A} & \mathrm{G} & \mathrm{N} & \mathrm{L} & \mathrm{A} & \mathrm{D} & \mathrm{F} & \mathrm{F} & \mathrm{P} & \mathrm{V} & \mathrm{F} & \mathrm{R} & \mathrm{Y} & \mathrm{F} & \mathrm{P} & \mathrm{S} & \mathrm{P} & \mathrm{S} & & 200\end{array}$

CTG AGA AAg ATA GTC CAg TAC GTT CGC AGg ATG AAC AGG TTC ATG GAG CGg AAC ATC GAg 660

$\begin{array}{llllllllllllllllllllllll}\mathrm{L} & \mathrm{R} & \mathrm{K} & \mathrm{I} & \mathrm{V} & \mathrm{Q} & \mathrm{Y} & \mathrm{V} & \mathrm{R} & \mathrm{R} & \mathrm{M} & \mathrm{N} & \mathrm{R} & \mathrm{F} & \mathrm{M} & \mathrm{E} & \mathrm{R} & \mathrm{N} & \mathrm{I} & \mathrm{E} & & 220\end{array}$

GAA CAC ATT GAC ACC TTT GAT AAG AAC CGT ATC CGA GAC ATT ACA GAT GCC CT

$\begin{array}{lllllllllllllllllll}\text { E } & \text { H } & \text { I } & \text { D } & \text { T } & \text { F } & \text { D } & \text { K } & \text { N } & \text { R } & \text { I } & \text { R } & \text { D } & \text { I } & \text { T } & \text { D } & \text { A } & 237\end{array}$

Fig. 1 Partial nucleotide sequence (713 bp) of tilapia cytochrome P450 1D1 cDNA and its deduced amino acid (237) residues 
representing a portion of the tilapia CYP1D1 cDNA ORF and encoding 237 amino acids (Fig. 1). The nucleotide sequence was registered in GenBank under accession number MF694263.

Amino acid sequence comparison

The percent identities shared by the deduced amino acid sequence of $O$. niloticus CYP1D1 with the sequences of CYP1D1 from other species are shown in Table 2. The highest identity was $81 \%$, with Fundulus heteroclitus CYP1D1, followed by $68.8 \%$ with zebrafish CYP1D1, $47.7 \%$ with Western clawed frog CYP1D1, and $47.2 \%$ with both crab-eating macaque CYP1D1 and rhesus monkey CYP1D1. Moreover, the percent identities shared by the deduced amino acid sequence of $O$. niloticus CYP1D1 with the sequences of CYP1 from other species are shown in Table 3. The highest identities were found with fish CYP1As (43.2\% with tilapia CYP1A1, 43.9\% with Japanese eel CYP1A1, 42.8\% with zebrafish CYP1A1, $41.5 \%$ with plaice CYP1A1, and $43.8 \%$ with scup CYP1A1), followed by fish CYP1B1s $(36.8 \%$ with tilapia CYP1B1, 35.5\% with fugu CYP1B1, and $34.9 \%$ with carp CYP1B1) and fish CYP1C1s (36.1\% with tilapia CYP1C1 and 37.5\% with Japanese eel CYP1C1).

\section{Phylogenetic tree}

Figure 2 shows that tilapia CYP1D1 is more closely related to $F$. heteroclitus CYP1D1 than to CYP1D1 genes from other species. Figure 3 shows that the amino acid sequence of tilapia CYP1D1 is more similar to those of CYP1As than to those of CYP1B1s or CYP1C1s.

CYP1D1 mRNA levels in different tissues of BaP-treated fish

Real-time RCR results (Fig. 4) revealed higher expression levels of CYP1D1 mRNA in different tissues (including muscles, gills, liver, intestine, and bile acid) of tilapia fish treated with BaP compared with the same fish tissues in the control group. The highest expression levels of CYP1D1 mRNA were observed in muscles (16.11), followed by gills (6.06), liver (5.94), and intestine (4.92), while very low expression levels were observed in bile acid (0.16), compared with the control sample.

\section{Discussion}

CYP1 family genes induced by AHRs play an important role in metabolism of the xenobiotic PAH. Therefore, understanding the evolution of fish CYP1s and their association with AHRs is important for the prediction and evaluation of the ability of fish to adapt to xenobiotic risk (Kawai et al. 2012).

In this study, we identified and cloned a partial nucleotide sequence of Nile tilapia CYP1D1 and investigated the effect of the environmental pollutant and AHR agonist BaP on the expression of this sequence.

Table 2 Percent identities of the deduced amino acid sequences of CYP1D1 gene subfamilies

\begin{tabular}{|c|c|c|c|c|c|}
\hline & $\begin{array}{l}\text { Crab-eating macaque } \\
\text { CYP1D1 }\end{array}$ & $\begin{array}{l}\text { Fundulus heteroclitus } \\
\text { CYP1D1 }\end{array}$ & $\begin{array}{l}\text { Rhesus monkey } \\
\text { CYP1D1 }\end{array}$ & $\begin{array}{l}\text { Western clawed frog } \\
\text { CYP1D1 }\end{array}$ & $\begin{array}{l}\text { Zebrafish } \\
\text { CYP1D1 }\end{array}$ \\
\hline Tilapia CYP1D1 & 47.2 & 81.0 & 47.2 & 47.7 & 68.8 \\
\hline $\begin{array}{l}\text { Crab-eating macaque } \\
\text { CYP1D1 }\end{array}$ & & 47.5 & 98.9 & 53.4 & 48.5 \\
\hline $\begin{array}{l}\text { Fundulus heteroclitus } \\
\text { CYP1D1 }\end{array}$ & & & 47.7 & 48.1 & 69.4 \\
\hline $\begin{array}{l}\text { Rhesus monkey } \\
\text { CYP1D1 }\end{array}$ & & & & 53.4 & 48.7 \\
\hline $\begin{array}{l}\text { Western clawed frog } \\
\text { CYP1D1 }\end{array}$ & & & & & 48.3 \\
\hline
\end{tabular}




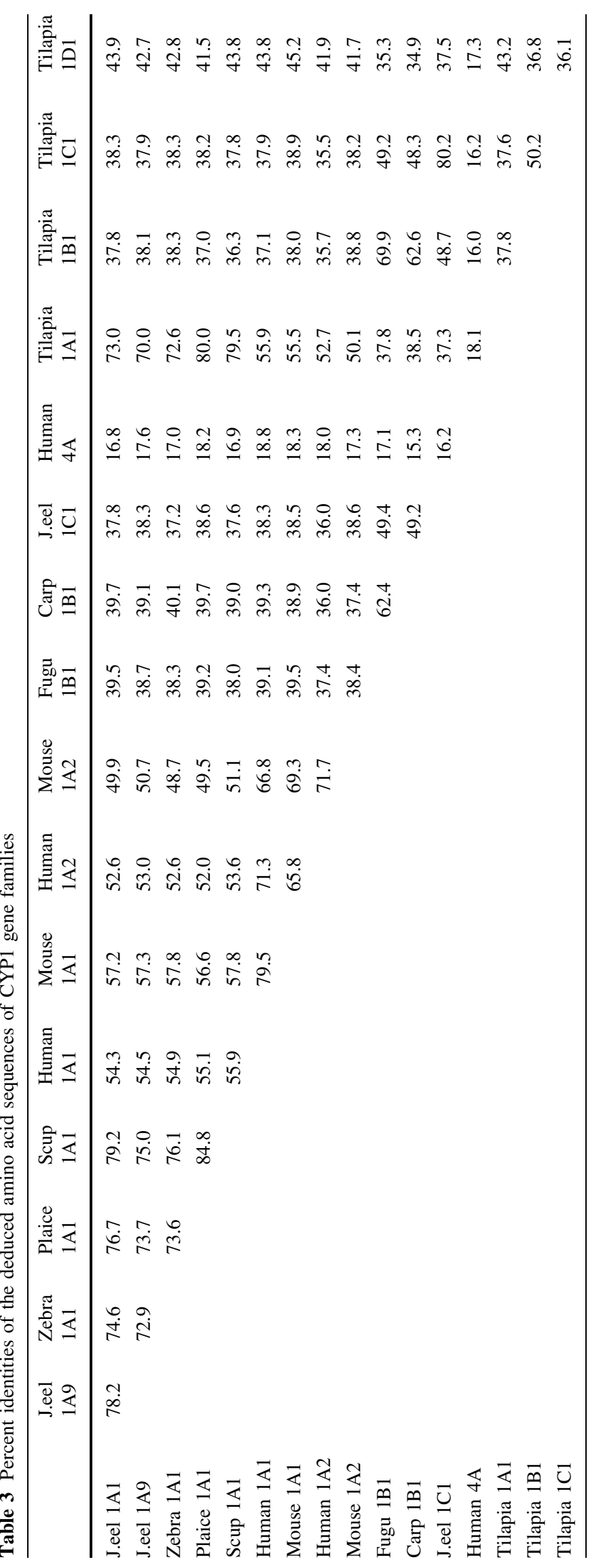




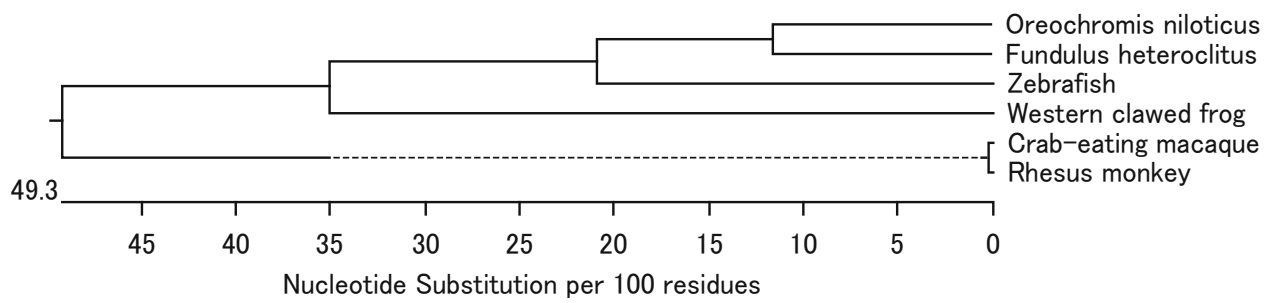

Fig. 2 Phylogenetic tree of CYP1D1 cDNAs using amino acid sequences

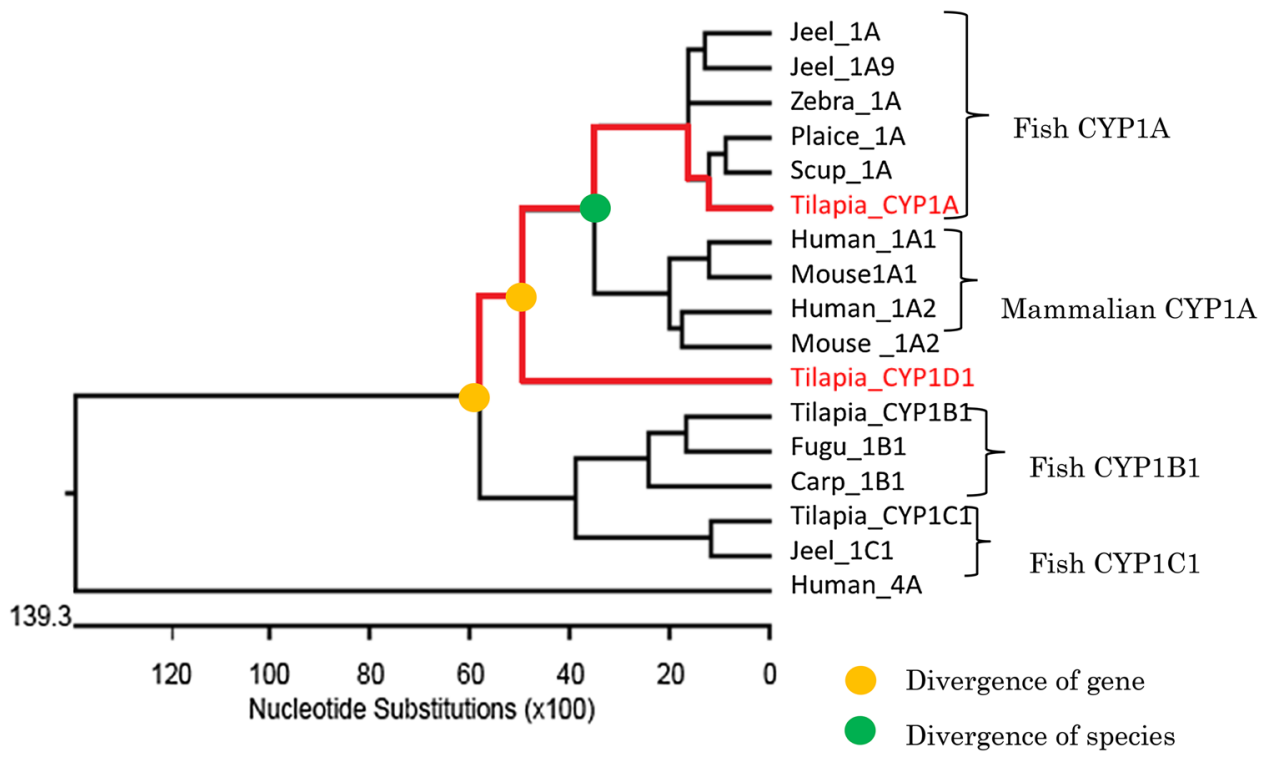

Fig. 3 Phylogenetic tree of CYP1 family cDNAs using amino acid sequences

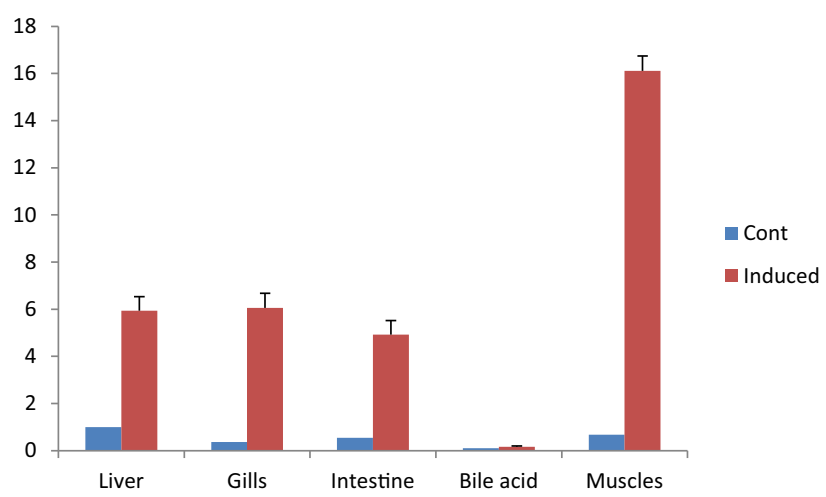

Fig. 4 CYP1D1 mRNA levels in different tissues of BaP-treated fish

Vertebrate CYP1 subfamilies include the CYP1A, CYP1B, CYP1C, and CYP1D subfamilies. Recently, the CYP1D subfamily was identified in non-mammalian vertebrates such as fish (Goldstone et al. 2009). In addition, five P450 type 1 family enzymes (CYP1A, CYP1B, CYP1C1, CYP1C2 and CYP1D) have been isolated from different fish species. CYP1D1 was first cloned in the freshwater fish species medaka (Oryzias latipes) by Goldstone et al. 2009. Since then, these enzymes have been isolated from the three-spined stickleback (Gasterosteus aculeatus), killifish, and zebrafish (Goldstone and Stegeman 2008; Zanette et al. 2009). Characterization of the CYP1D subfamily of genes can provide us with much information that will aid the understanding of CYP1 regulation and evolution (Kawai et al. 2012). 
We successfully cloned a partial nucleotide sequence of the tilapia CYP1D1 cDNA ORF consisting of 713 bp, encoding 237 amino acids. Phylogenetic analyses grouped tilapia CYP1D1 together with predicted CYP1D1 sequences from other fish species. Furthermore, this CYP1D1 subfamily was placed in a common clade with CYP1As. Thus, CYP1As and tilapia CYP1D together constitute one clade, while CYP1Bs and CYP1Cs constitute another clade. This finding demonstrates a close evolutionary relationship between CYP1D1 and CYP1A and suggests a common ancestral origin for both of these genes (Goldstone et al. 2009).

The cytochrome P450 1 (CYP1) gene family is one of most highly responsive gene families to AHR agonist exposure (Jönsson et al. 2011). These genes are upregulated by AHR activation and induced by several components (Goldstone et al. 2009). Amino acid sequence domain analysis of fish CYP1B, CYP1C and CYP1D revealed the uniqueness of the catalytic functions or substrates of these proteins (Uno et al. 2012); however, all previous studies stated that the CYP1D1 gene family is expressed in fish but is not induced by AHR agonists such as PCB126, TCDD, or 6-formylindolo[3,2-b]carbazole (FICZ) (Goldstone and Stegeman 2008; Goldstone et al. 2009; Jönsson et al. 2009; Zanette et al. 2009).

The real-time PCR results in this study showed that CYP1D1 is induced in different Nile tilapia fish tissues by the AHR agonist BaP. Similar findings were reported by Scornaienchi et al. (2010), who observed low activity of zebrafish CYP1D1 towards BaP, with a distinct spectrum of BaP metabolites. The BaP-6,12- and BaP-1,6-dione metabolites were the major products of CYP1D1 metabolism. However, CYP1D1 produced no detectable BaP-7,8-diol and very little 3-OH-BaP, which were major metabolites of all other zebrafish CYP1s. This difference in regioselectivity towards BaP suggests that the function of CYP1D1 may be different from that of other CYP1s. Many previous studies have reported that the number of XRE regions upstream of fish CYP1D1 is lower than that found for other CYP1 family genes and that AhR ligands did not induce CYP1D1 gene expression (Goldstone et al. 2009; Zanette et al. 2009; Jönsson et al. 2009), indicating that fish CYP1D1 is regulated by different mechanisms and could be induced via other signal cascades.

The highest expression of tilapia CYP1D1 mRNA was reported in the muscles, followed by the gills, liver, and intestine. Our previous studies on the expression levels of the CYP1 family in tilapia following intraperitoneal injection of $\mathrm{BaP}$ showed distinct induction of CYP1A1 expression in the liver and intestine (Hassanin et al. 2009), while the highest expression levels of CYP1B1 and CYP1C1 were recorded in the liver, followed by the intestine and muscles (Hassanin et al. 2012, 2013). The differences in the expression of tilapia CYP1 isoforms are likely indicative of their roles in vivo.

In conclusion, to our knowledge, this is one of the first reports on the structure and expression pattern of CYP1D1 in Nile tilapia fish. Our results showed that tilapia CYP1D1 was induced by BaP, while all previous studies reported that CYP1D1 seems to have very minimal, if any, activity towards all other AHR agonists, indicating that the function of CYP1D1 is different from that of other CYP1s. This result will be of great importance for the identification of the possible contribution of CYP1D1 in the bioactivation or inactivation of ecological contaminants and for the possible application of this gene as a biomarker in fish.

\section{Compliance with ethical standards}

Conflict of interest None of the authors have any conflict of interest regarding the research described in this article.

Open Access This article is distributed under the terms of the Creative Commons Attribution 4.0 International License (http:// creativecommons.org/licenses/by/4.0/), which permits unrestricted use, distribution, and reproduction in any medium, provided you give appropriate credit to the original author(s) and the source, provide a link to the Creative Commons license, and indicate if changes were made.

\section{References}

Almeida JA, Diniz YS, Marques SF, Faine LA, Ribas BO et al (2002) The use of the oxidative stress responses as biomarkers in Nile tilapia (Oreochromis niloticus) exposed to in vivo cadmium contamination. Environ Int 27:673-679

Cousin X, Cachot J (2014) PAHs and fish-exposure monitoring and adverse effects-from molecular to individual level. Environ Sci Pollut Res 21:13685-13688

Figueiredo-Fernandes A, Fontaínhas-Fernandes A, Monteiro RAF, ReisHenriques MA, Rocha E (2006) Effects of the fungicide mancozeb in the liver structure of Nile tilapia, Oreochromis niloticus: assessment and quantification of induced cytological changes using qualitative histopathology and the stereological point-sampled intercept method. Bull Environ Contam Toxicol 76:249-255 
Goldstone JV, Stegeman JJ (2008) Gene structure of the novel cytochrome P4501D1 genes in stickleback (Gasterosteus aculeatus) and medaka (Oryzias latipes). Mar Environ Res 66:19-20

Goldstone JV, Goldstone HM, Morrison AM, Tarrant A, Kern SE, Woodin BR, Stegeman JJ (2007) Cytochrome P450 1 genes in early deuterostomes (tunicates and sea urchins) and vertebrates (chicken and frog): origin and diversification of the CYP1 gene family. Mol Biol Evol 24:2619-2631

Goldstone JV, Jönsson ME, Behrendt L, Woodin BR, Jenny MJ, Nelson DR, Stegeman JJ (2009) Cytochrome P450 1D1: a novel CYP1A-related gene that is not transcriptionally activated by PCB126 or TCDD. Arch Biochem Biophys 482:7-16

Gravato C, Santos MA (2003) Genotoxicity biomarkers' association with B(a)P biotransformation in Dicentrarchus labrax L. Ecotoxicol Environ Saf 55:352-358

Hassanin AAI, Kaminishi Y, Osman MM, AbdelWahad ZH, El-Kady MA, Itakura T (2009) Development and application of a real-time quantitative PCR assay for determining expression of benzo-apyrene-inducible cytochrome P450 1A in Nile tilapia (Oreochromis niloticus). Afr J Biotech 8(23):6588-6595

Hassanin AAI, Kaminishi Y, Funahashi A, Itakura T (2012) Cytochrome P450 1C1 complementary DNA cloning, sequence analysis and constitutive expression induced by benzo-a-pyrene in Nile tilapia (Oreochromis niloticus). Aquat Toxicol 109:17-24

Hassanin AAI, Osman MM, Kaminishi Y, ElKady MA, Itakura T (2013) Molecular characterization of cytochrome P450 1B1 and effect of benzo(a) pyrene on its expression in Nile tilapia (Oreochromis niloticus). Afr J Biotech 12(48):6682-6690

Hellemans J, Mortier G, De Paepe A et al (2007) qBase relative quantification framework and software for management and automated analysis of real-time quantitative PCR data. Genome Biol 8:R19

Jönsson ME, Jenny MJ, Woodin BR, Hahn ME, Stegeman JJ (2007) Role of AHR2 in the expression of novel cytochrome P450 1 family genes, cell cycle genes, and morphological defects in developing zebrafish exposed to 3,3',4,4',5-pentachlorobiphenyl or 2,3,7,8-tetrachlorodibenzo-p-dioxin. Toxicol Sci 100:180-193

Jönsson ME, Franks DG, Woodin BR, Jenny MJ, Garrick RA, Behrendt L, Hahn ME, Stegeman JJ (2009) The tryptophan photoproduct 6-formylindolo[3,2-b] carbazole (FICZ) binds multiple AHRs and induces multiple CYP1 genes via AHR2 in zebrafish. Chem Biol Interact 181:447-454

Jönsson ME, Gao K, Olsson JA, Goldstone JV, Brandt I (2010) Induction patterns of new CYP1 genes in environmentally exposed rainbow trout. Aquat Toxicol 98:311-321

Jönsson ME, Berg C, Goldstone JV, Stegeman JJ (2011) New CYP1 genes in the frog Xenopus (Silurana) tropicalis: induction patterns and effects of AHR agonists during development. Toxicol Appl Pharmacol 250:170-183

Kawai YK, Ikenaka Y, Fujita S, Ishizuka M (2012) The CYP1D subfamily of genes in mammals and other vertebrates. Mamm Genome 21(5-6):320-329

Nebert DW, Russell DW (2002) Clinical importance of the cytochromes P450. Lancet 360:1155-1162

Office of the Federal Registration (OFR) (1982) Appendix A: priority pollutants. Fed Reg 47:52309

Payne JF, Penrose WR (1975) Induction of aryl hydrocarbon (benzo(a)pyrene) hydroxylase in fish by petroleum. Bull Environ Contam Toxicol 14:112-116

Peters LD, Morse HR, Waters R, Livingstone DR (1997) Responses of hepatic cytochrome P450 1A and formation of DNAadducts in juveniles of turbot (Scophthalmus maximus L.) exposed to water-borne benzo[a]pyrene. Aquat Toxicol 38:67-82

Saad M, Cavanaugh K, Verbueken E, Pype C, Casteleyn C, Gienneken CV, Cruchten SV (2016) Xenobiotic metabolism in the zebrafish: a review of the spatiotemporal distribution, modulation and activity of cytochrome P450 families 1 to 3 . J Toxicol Sci 41(1):1-11

Sambrook J, Russel DV (2001) Molecular Cloning: a Laboratory Manual, vol 1, 3rd edn. Cold Spring Harbor Laboratory, NY, pp 7.13-7.17

Savas U, Bhattacharyya KK, Christou M, Alexander DL, Jefcoate CR (1994) Mouse cytochrome P-450EF, representative of a new 1B subfamily of cytochrome P450s. Cloning, sequence determination and tissue expression. J Biol Chem 269:14905-14911

Scornaienchi ML, Thornton C, Willett KL, Wilson JY (2010) Functional differences in the cytochrome P450 1 family enzymes from zebrafish (Danio rerio) using heterologously expressed proteins. Arch Biochem Biophys 502:17-22

Summerfelt RC, Smith LS (1990) Anaesthesia, surgery and related techniques. In: Schreck CB, Moyle PB (eds) Methods for fish biology. American Fisheries Society, Bethesda, pp 213-272

Tsuji PA, Walle T (2007) Benzo[a]pyrene-induced cytochrome P450 1A and DNA binding in cultured trout hepatocytesinhibition by plant polyphenols. Chem Biol Interact 169:25-31

Uno Y, Uehara S, Murayama N, Yamazaki H (2011) CYP1D1, pseudogenized in human, is expressed and encodes a functional drug-metabolizing enzyme in cynomolgus monkey. Biochem Pharmacol 81:442-450

Uno T, Ishizuka M, Itakura T (2012) Cytochrome P450 (CYP) in fish. Environ Toxicol Pharmacol 34:1-13

Zanette J, Jenny MJ, Goldstone JV, Woodin BR, Watka LA, Bainy AC, Stegeman JJ (2009) New cytochrome P450 1B1, 1C2 and 1D1 genes in the killifish Fundulus heteroclitus: basal expression and response of five killifish CYP1s to the AHR agonist PCB126. Aquat Toxicol 93:234-243

Zhang Y, Savas U, Alexander DL, Jefcoate CR (1998) Characterization of the mouse CYP1B1 gene identification of an enhancer region that directs aryl hydrocarbon receptor-mediated constitutive and induced expression. J Biol Chem 273:5174-5183

\section{Publisher's Note}

Springer Nature remains neutral with regard to jurisdictional claims in published maps and institutional affiliations. 